\title{
A Review on Heavy Metal Residues in Indian Milk and their Impact on Human Health
}

\author{
Choodamani Chandrakar $^{1 *}$, Sudhir Kumar Jaiswal' ${ }^{2}$, A.K. Chaturvedani ${ }^{3}$, \\ Sambhuti Shankar Sahu ${ }^{4}$, Monika ${ }^{5}$ and Upendra Wasist ${ }^{6}$
}

${ }^{1}$ Department of Veterinary Public Health and Epidemiology, ${ }^{2}$ Division of Poultry Science, ${ }^{3}$ Division of Extension Education, College of Veterinary Science and Animal Husbandry,

${ }^{5}$ Department of Veterinary Pharmacology and Toxicology, ${ }^{6}$ Department of Livestock and Production Management, Anjora, Durg, (C.G.) 491001, India

${ }^{4}$ Department of Livestock Production and Management, College of Veterinary Science and Animal Husbandry, Bilaspur (C.G.) 495001, India

*Corresponding author

\section{A B S T R A C T}

\section{Keywords}

Heavy metal, Milk, Food, Toxicity

\section{Article Info}

Accepted:

10 April 2018

Available Online:

10 May 2018
In recent scenario due to indiscriminate human activities the heavy metal pollution is very much concerned because of their toxicity for animal and human beings and their lack of biodegradability. Heavy metal toxicity is linked with a number of diseases but the severity of situation multiplies too many folds if these heavy metals are found in milk, which is the basic food item of vulnerable age group of people. Heavy metal when reaches human and animal body through various absorption pathways such as direct ingestion, dermal contact, diet through the soil-food chain, inhalation and oral intake may seriously affect their health. Contamination of environment leads to contamination of food chain, which the main rout the entry of heavy metal in the animal body which ultimately causes contamination of milk and animal originated food. Therefore, several management practices like treatment of industrial water, use of heavy metal free water and feed for animal production can reduce the heavy metal level in the milk.

\section{Introduction}

Milk and milk products are major constituents of the daily diet in India as well as whole world. These products are major sources of nutrition, especially for children, due to the availability of almost all essential macro and micronutrients. Milk is the abundant sources of calcium, vitamin D, riboflavin, and phosphorus, protein, potassium, vitamin A, vitamin B-12 and niacin are also found in good amounts. The most frequent consumers of milk and dairy products are infants and elderly, two age demographics typically described as particularly vulnerable to heavy metal exposure risks. Therefore, the presence of any toxic material in milk is a matter of serious concern. In response, stringent rules have been adopted for the toxic materials in milk and milk products (Ismail et al., 2017).

Environmental pollution occurs due to 
industrialization and extraction of natural resources in large scale, and it is responsible for degradation of environmental health. Among all kinds of pollution, heavy metals make a significant contribution to the environmental pollution (Nedel Koska and Doran, 2000). The metal present in soil-plant system can easily enter into food chain and also cause risk for humans, animals, plants and whole environment of our modern society (Farouk et al., 2011).

Heavy metals are listed as priority pollutants by the United States Environmental Protection Agency (UEPA). There are more than 70,000 chemicals in use in the world (Cairns et al., 1988). For the level of toxicity, lead, mercury, arsenic and cadmium are ranked first, second, third, and sixth, respectively, in the list of US Agency for Toxic Substances and Disease Registry (ATSDR). The problem of heavy metal pollution is emerging as a matter of concern at local, regional and global scales. Normally, the rate of transfer of heavy metals from forage to milk is very low and is reported as 1:500 (Bluthgen, 2000), due to the fact that mammary glands prevent the entry of toxic metals by acting as biological filters (Nag, 2010). Apart from industries, roadways and automobiles contribute substantially to environmental burden of heavy metals since particulate matters in traffic emissions include heavy metals like lead, cadmium and arsenic (Onat et al., 2013). Application of sewage sludge in agricultural fields resulted in the accumulation of heavy metals in the soil and consequently to plants (Nogueira et al., 2013). Groundwater can be contaminated with metals directly by infiltration of leachate from land disposal of solid wastes, liquid sewage or sewage sludge, leachate from mine tailings and other mining wastes, deep-well disposal of liquid wastes, seepage from industrial waste lagoons or from other spills and leaks from industrial metal processing facilities (e.g., steel plants, plating shops, etc.). Metal concentrations in foodstuff depend on quality of water, soil characteristics etc which can affect the bioavailability of elements Heavy metals may enter in the dairy products by different ways. These include atmospheric deposition; land application of inorganic fertilizers, use of agrochemicals like pesticides, herbicides etc. Heavy metals in milk may come from the milk containers, during processing, through contaminated water used for agriculture, livestock feed, and the surrounding environment of milkproducing animals (Zain et al., 2016).

Heavy metals can be defined as elements having a specific gravity above $5 \mathrm{~g} / \mathrm{cm}^{3}$, or atomic weights in the range of 63.5$200.6 \mathrm{~g} / \mathrm{mol}$ and are toxic to humans even in minute quantities (Tekaya et al., 2013, Gumpu et al., 2015). Heavy metals are nonbiodegradable or thermo degradable, and are ubiquitous in nature (Ismail et al., 2014). Some mineral elements like Iron $(\mathrm{Fe})$, Zinc $(\mathrm{Zn})$, Nickel $(\mathrm{Ni})$, and Copper $(\mathrm{Cu})$ can also be categorized as heavy metals when they are found in food commodities beyond certain limits (Valko et al., 2005).

Milk is an important food received from animal origin; if the animal body was contaminated it was an excretion of the mammary gland can carry numerous xenobiotic substances. This constitutes a great risk factor for dairy products and above all, for the health of the consumer which includes infants and the elderly. Therefore, determination of the residual concentrations of metals in milk could be an important 'direct indicator' to assess hygienic status of the milk, as well as an 'indirect indicator' of the degree of pollution of the environment in which the milk was produced. Transfer of toxic elements to human food chain is a concrete danger that has to be faced in the near future. Living organisms require varying amounts of few heavy metals. Iron, cobalt, copper, manganese, 
molybdenum and zinc are required by humans in trace amounts. All metals are toxic at higher concentrations (Singh et al., 2011). Other heavy metals such as mercury, arsenic, cadmium and lead are toxic metals that have no known vital or beneficial effect on organisms, and their accumulation over time in the bodies of animals can cause serious illness.

Heavy metals disrupt metabolic functions in human beings. Excess accumulation disrupts the function of vital organs and glands such as heart, brain, kidneys, bone, liver, etc. These metals displace the vital nutritional minerals from their original place, and hinder their biological function. These metals can enter into our body through consumption of foods, beverages, skin exposure and inhaled air. Among different heavy metals, chronic exposure to low doses of cancer-causing heavy metals may induce many types of cancer.

This review contains an overview of the major heavy metals reported in milk in different states of India. The sources of contamination, health impacts, regulations, and mitigation techniques of heavy metals in milk are also discussed.

\section{Sources of heavy metals in milk}

Due to continuous industrialization and urbanization activities, heavy metal pollution becomes a major cause of environmental degradation. Heavy metals are commonly found in nature and their concentrations in food items are increasing day by day as a result of utilization of untreated sewage water and industrial effluents for irrigation of crops. Among different metals, it was suggested that $\mathrm{Cd}$ would be the most mobile element in the soil and more available to crop. Industrial emissions of contaminant to the atmosphere which is finally deposited on soil or dumping of industrial wastes on disposal land may cause problem in the environment beyond limit. In India, many urban and dense cities with significant industrial waste generation have been found to have contaminated soil. Metals may contaminate animal milk through instruments and machinery used in processing and distribution of milk. For this reason, processed milk is reported to have higher concentrations of heavy metals as compared to raw milk (Anetta, 2012).

Furthermore, heavy metals may also enter into milk through contaminated animal feed by the routes of irrigation with polluted canal or sewage water, the application of pesticides and fungicides, and the presence of industries near the animal feed areas (Cai et al., 2009, Iftikhar et al., 2014). Simsek et al., (2000) studied the effect of environmental pollution on the heavy metal content of raw milk and found higher heavy metal concentration in the milk from areas in proximity to industrial zones and areas with significant vehicular traffic while lower heavy metal concentrations in the milk samples from rural areas. Kazi et al., (2009) also reported higher lead (Pb) levels in milk samples collected from shops and in processed milk as compared to milk samples collected directly from the farms. In this way, heavy metal concentration in milk can be an indicator of environmental pollution (Pilarczyk et al., 2013).

\section{Regulatory limits}

Regulatory focus on heavy metal contamination in milk is very essential due to its consumption by different age groups and most likely by children and older persons comprises most vulnerable group for heavy metal toxicity. That's why a number of regulatory agencies have established permissible limits for $\mathrm{Pb}$ and $\mathrm{Cd}$ in milk due to their significant toxicity. The maximum permissible level of $\mathrm{Pb}$ in milk recommended 
by Codex Alimentarius Commission (2015) and European Union Commission (EC) no. 1881 European Union (2006) is $0.02 \mathrm{mg} / \mathrm{ml}$. Maximum permissible limit for $\mathrm{Cd}$ in milk recommended by FAO/WHO (Codex Alimentarius Commission, 1999) is $0.01 \mathrm{mg} / \mathrm{ml}$. According to Indian regulations (FSSAI, 2011), the maximum permissible limits for $\mathrm{Pb}$ in milk are 0.02 and $0.1 \mathrm{mg} / \mathrm{ml}$. The maximum permissible limit for milk established by European Union Commission (European Union, 2006) is $0.1 \mathrm{mg} / \mathrm{ml}$. The maximum permissible limits for $\mathrm{Ni}$ and $\mathrm{Co}$ in milk are not reported by any of the regulatory agencies reviewed in this study.

The prevalence of heavy metals in milk above the permissible limits is reported mostly from the developing countries mainly due to the unhygienic conditions of processing, contaminated feed and water used for animals, and the negligence as well as unawareness of the personnel involved in dairy business. Although strict regulations exist for the control of heavy metals in milk but these regulations are not of significance for the developing countries where most of the milk is consumed in unprocessed form where the milkmen supply milk directly to homes without any testing by the regulatory agencies. Therefore, the scope of the regulations regarding heavy metals in milk and milk products is only limited to developed countries or to the processed milk consumed in developing countries.

Indian scenario of contamination of milk with heavy metal

Heavy metals appeared as consistent contaminants of different food products during the last few years most probably due to the increase in industrial activities, preparation of various varieties of processed foods involving a number of machines and also due to long distance travel by food items where metallic contaminants might enter in food items at a number of points. In present review a number of reports have shown the elevated levels of $\mathrm{Pb}$ and $\mathrm{Cd}$ in milk and milk products while the contamination of $\mathrm{Hg}$ and $\mathrm{As}$ is reported less. However, it is pertinent to mention that the reports of metal contamination in milk and milk products presented below are the findings of various researchers from different part of India where different analytical techniques were used and therefore the purpose of data presented below is just to give an idea of the levels of various metallic contaminants in milk and milk products (Table 1).

\section{Heavy metal toxicity}

Metal toxicity can appear due to the intake of a metal beyond certain limit. Metal toxicity through milk is a more serious issue as compared to other foods due to higher consumption of milk by the most vulnerable age groups, that is, infants and elderly people (FAO, 2017).

$\mathrm{Ni}, \mathrm{Fe}, \mathrm{Zn}, \mathrm{Co}$, and $\mathrm{Cu}$ are reported to have some health bene fits for humans because they work as co-factor for various enzyme systems but yet their intake beyond certain limits may create health risks while $\mathrm{Pb}, \mathrm{Cd}$, and $\mathrm{Hg}$ have no reported health benefits. The residual concentration of heavy metals like $\mathrm{Pb}$ and $\mathrm{Cd}$ in animal milk is reported to increase with an increase in animal age (Najarnezhad et al., 2015).

Metal toxicity depends on various number of factors the more important of which are route of entry in body, age, and sex of the exposed person, intake level, and the state of metal and its rate of absorption (Mertz, 1986).Buffalo milk is reported to have more $\mathrm{Pb}$ and $\mathrm{Cd}$ as compared to cow milk (Iqbal et al., 2011). Highly toxic chemicals like lead, mercury, cadmium, etc. and its effect on health as shown in Table 2. 
Table.1 Heavy metal residues in milk samples

\begin{tabular}{|c|c|c|c|c|c|c|c|}
\hline S. No. & Place & Milk Type & Sample (n) & Range( $(\mu \mathrm{g} / \mathrm{ml})$ & Mean $(\mu \mathrm{g} / \mathrm{ml})$ & Analytical Method & $\begin{array}{l}\text { Reference } \\
\end{array}$ \\
\hline \multirow[t]{7}{*}{01} & \multirow[t]{7}{*}{ Palghar (Maharashtra) } & \multirow[t]{7}{*}{ Buffalo milk } & \multirow[t]{7}{*}{28} & $\mathrm{Zn}-0.111$ to 7.23 & 4.23 & \multirow[t]{7}{*}{ ICP-AES } & \multirow[t]{7}{*}{ Nirgude et al., 2015} \\
\hline & & & & Fe- 0.111 to 7.723 & 4.25 & & \\
\hline & & & & $\mathrm{Pb}-0.065$ to 0.137 & 0.089 & & \\
\hline & & & & Ba- 0.148 to 0.304 & 0.253 & & \\
\hline & & & & Mn- 0.027 to 0.406 & 0.124 & & \\
\hline & & & & $\mathrm{Cr}-0.014$ to 1.606 & 0.278 & & \\
\hline & & & & $\mathrm{Ni}-0.04$ to 0.749 & 0.094 & & \\
\hline \multirow[t]{2}{*}{02} & \multirow[t]{2}{*}{ Hyderabad } & \multirow[t]{2}{*}{ Buffalo milk } & \multirow[t]{2}{*}{30} & $\mathrm{~Pb}-$ & 0.22 & \multirow[t]{2}{*}{ F-AAS } & \multirow[t]{2}{*}{ Shailaja et al., 2014} \\
\hline & & & & $\mathrm{Zn}-$ & 3.96 & & \\
\hline \multirow[t]{5}{*}{03} & \multirow[t]{5}{*}{ Hosur, (Tamilnadu) } & \multirow[t]{5}{*}{ Goat milk } & \multirow[t]{5}{*}{144} & As- $0.082-0.056$ & - & \multirow[t]{5}{*}{ ICP-OES } & \multirow[t]{5}{*}{ Dhanalakshmi et al., 2013} \\
\hline & & & & Cd-0.030-0.016 & - & & \\
\hline & & & & $\mathrm{Pb}-0.064-0.052$ & - & & \\
\hline & & & & $\mathrm{Hg}-0.007-0.004$ & - & & \\
\hline & & & & Ni-0.069-0.067 & - & & \\
\hline \multirow[t]{2}{*}{04} & \multirow[t]{2}{*}{ Vadodara } & Milk and milk product & - & Cd- & 1.51 & \multirow[t]{2}{*}{ AAS } & \multirow[t]{2}{*}{ Chandorkar et al.,2013 } \\
\hline & & Branded milk & - & $\mathrm{Cd}-$ & 0.23 & & \\
\hline 05 & Delhi & Branded milk & & $\mathrm{Zn}$ & 2.28 & Voltammetric determination & Raina et al.,2013 \\
\hline \multirow[t]{5}{*}{06} & \multirow[t]{5}{*}{ Mumbai } & \multirow{5}{*}{$\begin{array}{l}\text { Cow milk of different } \\
\text { brands }\end{array}$} & \multirow[t]{5}{*}{15} & $\mathrm{Cu}-0.039-37.29$ & - & \multirow[t]{5}{*}{ ICP-AES } & Zodape et al., 2012 \\
\hline & & & & $\mathrm{Zn}-0.496-0.786$ & - & & \\
\hline & & & & $\mathrm{Cr}-0.013-0.175$ & - & & \\
\hline & & & & $\mathrm{Pb}-0.139-5.904$ & - & & \\
\hline & & & & $\mathrm{Hg}-0.015-0.023$ & - & & \\
\hline 07 & Singhbhum (Jharkhand) & Cow milk & 60 & $\mathrm{Fe}-0.2-13.2$ & 4.91 & AAS & Giri et al.,2011 \\
\hline & & & & Mn-0.17-0.59 & 0.29 & & \\
\hline & & & & $\mathrm{Zn}-1.66-7.13$ & 4.77 & & \\
\hline & & & & $\mathrm{Cu}-0.23-2.03$ & 0.56 & & \\
\hline & & & & $\mathrm{Ni}-0.31-0.63$ & 0.48 & & \\
\hline 08 & Tiruvallur (Tamilnadu) & Buffalo milk & 216 & $\mathrm{~Pb}-\mathrm{ND}-0.19$ & 8.62 & AAS & Sahayaraj and Ayyadurai, 2009 \\
\hline 09 & Bangalore & Cow milk & - & $\mathrm{Fe}-0.33$ & - & AAS & Lokeshwari and \\
\hline & & & & $\mathrm{Zn}-1.83$ & - & & Chandrappa, 2006 \\
\hline & & & & Cd-0.02 & - & & \\
\hline 10 & Various parts of India & $\begin{array}{c}\text { Cow milk from } \\
\text { Lead zinc Smelter area }\end{array}$ & 21 & $\mathrm{~Pb}-0.13-2.70$ & 0.844 & AAS & Swarup et al.,2005 \\
\hline 11 & Bombay City & Commercial milk & 75 & $\mathrm{Zn}-3.177$ & - & AAS & Tripathi et al., 1999 \\
\hline & & & & $\mathrm{Pb}-0.0017$ & - & & \\
\hline & & & & $\mathrm{Cu}-0.0017$ & - & & \\
\hline
\end{tabular}

ICP-AES: inductively coupled plasma atomic emission spectrophotometer; FAAS: flame atomic absorption spectrophotometer; ICP-OES: Inductively coupled plasma- optical emission spectrometry; AAS: atomic absorption spectrophotometer 
Table.2 Toxic metals and their effects on humans health

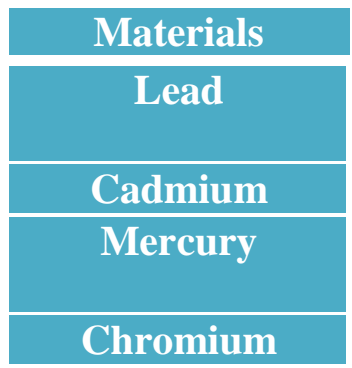

Chromium

\section{Toxic effect}

Kidney failure, central and peripheral nervous systems, damage to the reproductive systems

Long term cumulative poison, Bone disease

Chronic damage to brain, liver damage, causes damage to the central and peripheral nervous systems as well as the fetus

DNA damage, lung cancer

(Baccarelli and Bollati, 2007)

\section{Control of heavy metals in milk}

Due to haphazard industrial development heavy metals can be reached in the environment from industrial points into canals and rivers and other water bodies, through direct discharge and runoff of contaminated sites. This contaminated water also used in agriculture fields as irrigation purpose where animal feed is grown (Sansalone and Buchberger, 1997). These Ultimately leads to entrance of heavy metals in the milk supply through ingestion of metal contaminated feed or water by dairy animals or through utensils used in the transport and processing of milk and sometimes the milk men are involved in the adulteration of milk with dirty water like canal water which might be a great source of heavy metals.

Treatment of industrial waste water by adsorption of heavy metals from industrial waste water has been very crucial point to prevent the contamination of water bodies (Khan et al., 2008). Some potentially low-cost sorbents for heavy metals have been found effective, including sorbents that are waste products of some industrial processes (Bailey et al., 1999). These low-cost sorbents may be a more viable option in developing nation like India. In general, a widely used treatment technique is chemical precipitation using hydroxides (Kurniawan et al., 2006). More advanced treatment technologies such as Nano-Filtration (NF), Reverse Osmosis (RO), and Ion Exchange have also been found to be effective (Fu and Wang, 2011); however, these technologies may not be economically feasible in some developing nations due to higher cost.

Changes in the milk manufacturing process also helpful to reduce the contamination of milk by heavy metals. The water used for drinking of animal and the fodder of milking animal should be regularly monitored to evaluate the level of heavy metals. Precautions should be taken to avoid metal contamination during the handling, processing, and storage of milk and milk products, and only food grade materials should be used during these steps. Animal herds and the land used for the cultivation of animal fodder should be selected far from the industrial and heavy traffic areas to avoid the chances of metal contamination.

The practice of heavy metal detection should be continued to avoid possible contamination. Because heavy metals can cause a number of health implications in humans. Children and elderly people are more vulnerable to heavy metal exposure due to their high milk consumption rates. Rapid urbanization and industrialization, less strict regulations and environmental pollution can result in elevated levels of heavy metals in milk. It is also essential that farmers should be educated to reduce such contamination and should be encouraged to use the controlled amount of 
pesticides; to avoid the leaching of waste water and cultivation should be conducted in fields far away from industrial area as well as areas prone to contamination.

\section{References}

Anetor, J. I., 2012. Rising environmental cadmium levels in developing countries: threat to genome stability and health. Nigerian journal of physiological sciences. 27(2):103-15.

Anetta, L., 2012. Concentration of selected elements in raw and ultra-heat treated cow milk. Journal of microbiology, biotechnology and food sciences. 2: 795802.

Baccarelli, A. and Bollati, V., 2009. Epigenetics and environmental chemicals. Current opinion in pediatrics. 21(2): 243.

Bailey, S. E., Olin, T. J., Bricka, R. M. and Adrian, D. D., 1999. A review of potentially low-cost sorbents for heavy metals. Water Research. 33(11): 2469-79.

Bluthgen, A. H., 2000. Contamination of milk from feed.Bulletin of the international dairy federation. 356: 43-47.

Cai, Q., Long, M. L., Zhu, M., Zhou, Q. Z., Zhang, L. and Liu, J., 2009. Food chain transfer of cadmium and lead to cattle in a lead-zinc smelter in Guizhou, China. Environmental Pollution. 157(11): 3078-82.

Cairns, J., Smith, E. P. and Orvos, D., 1988. The problem of validating simulation of hazardous exposure in natural systems. In Proceedings of the 1988 Summer computer conference. The Society for Computer Simulation International, San Diego. 448-54.

Chandorkar, S. and Deota, P., 2013. Heavy metal content of foods and health risk assessment in the study population of Vadodara. Current World Environment. 8(2): 291-97.

Codex Alimentarius Commission. 1999. Discussion paper on maximum level for $\mathrm{Pb}$ in milk and secondary milk products.
Joint FAO/WHO food standards programme, twenty third session. Rome, Italy.

Codex Alimentarius Commission. 2015. General standard for contaminants and toxins in food and feed (CODEX STAN 193-1995): Codex Alimentarius Commission. http://www.fao.org/input/download/stand ards/17/CXS_193e_2015.pdf

Dhanalakshmi, B. and Gawdaman, G., 2013. Determination of heavy metals in goat milk through ICP-OES. Asian J. Dairy Food Res. 32: 186-90.

European Union. 2006. Commission regulation (EC) no. 1881/ 2006 setting maximum levels for certain contaminants in foodstuffs. Official journal of European Union. 364: 5-24.

FAO. 2017. Food and agricultural organization. Available from: http://www.fao.org/agriculture/dairygateway/milk-and-milkproducts/en/\#.VXCwWs9Viko.

Farouk, S., Mosa, A. A., Taha, A. A. and ElGahmery, A. M., 2011. Protective effect of humic acid and chitosan on radish (Raphanus sativus, L. var. sativus) plants subjected to cadmium stress. Journal of Stress Physiology \& Biochemistry. 7(2).

Food Safety and Standards (Contaminants, Toxins and Residues) Regulations (FSSAI). 2011. Ministry of Health and Family Welfare. (Food Safety and Standards Authority of India) https://www.suratmunicipal.gov.in/Conte nt/Documents/Downloads/FssAct/FssAct 1.pdf

Fu, F. and Wang, Q., 2011. Removal of heavy metal ions from wastewaters: a review. Journal of environmental management. 92(3): 407-18.

Giri, S., Singh, G., Jha, V. N. and Tripathi, R. M., 2011. Risk assessment due to ingestion of natural radionuclides and heavy metals in the milk samples: a case study from a proposed uranium mining area, 
monitoring and assessment. 175(1-4): $157-66$.

Gumpu, M. B., Sethuraman, S., Krishnan, U. M. and Rayappan, J. B. B., 2015. A review on detection of heavy metal ions in water-An electrochemical approach. Sensors and actuators B: chemical. 213: 515-33.

Iftikhar, B., Arif, S., Siddiqui, S. and Khattak, R., 2014. Assessment of Toxic Metals in Dairy Milk and Animal Feed in Peshawar, Pakistan. British Biotechnology Journal. 4(8): 883-93.

Iqbal, A., Khan, B. B., Kausar, A., 2011. Buffalo milk production potential and its comparative milk qualities. Special Issue 1201 of IDF International Symposium on sheep, Goat and other non-Cow Milk, Athens, Greece.

Ismail, A., Riaz, M., Akhtar, S., Goodwill, J. E. and Sun, J., 2017. Heavy metals in milk: global prevalence and health risk assessment. Toxin Reviews.1-12.

Ismail, A., Riaz, M., Akhtar, S., Ismail, T., Amir, M. and Zafar-ul-Hye, M., 2014. Heavy metals in vegetables and respective soils irrigated by canal, municipal waste and tube well waters. Food Additives \& Contaminants: Part B. 7(3): 213-19.

Kazi, T. G., Jalbani, N., Baig, J. A., Kandhro, G. A., Afridi, H. I., Arain, M. B., Jamali, M. K. and Shah, A. Q., 2009. Assessment of toxic metals in raw and processed milk samples using electrothermal atomic absorption spectrophotometer. Food and Chemical Toxicology. 47(9): 2163-69.

Khan, M. A., Rao, R. A. K. and Ajmal, M., 2008. Heavy metal pollution and its control through nonconventional adsorbents (1998-2007): a review. Journal of International Environmental Application and Science. 3(2): 101-41.

Kurniawan, T.A., Chan, G.Y., Lo, W.H. and Babel, S., 2006. Physico-chemical treatment techniques for wastewater laden with heavy metals. Chemical engineering journal. 118(1-2): 83-98.
Lokeshwari, H. and Chandrappa, G. T., 2006. Impact of heavy metal contamination of Bellandur Lake on soil and cultivated vegetation. Current science. 91(5): 62227.

Mertz, W. E. D., 1986. Trace elements in human and animal nutrition, vol. IandII, 5th ed., New York: Academic Press, 11018.

Nag, S. K., 2010. Contaminants in milk: routes of contamination, analytical techniques and methods of control. In: Improving the safety and quality of milk. Cambridge, UK: Woodhead Publishing Limited, 14678.

Najarnezhad, V., Jalilzadeh-Amin, G., Anassori, E. and Zeinali, V., 2015. Lead and cadmium in raw buffalo, cow and ewe milk from West Azerbaijan, Iran. Food Additives \& Contaminants: Part B. 8(2): 123-27.

Nedelkoska, T.V. and Doran, P. M., 2000. Hyper accumulation of cadmium by hairy roots of Thlaspi caerulescens. Biotechnology and Bioengineering. 67(5): 607-15.

Nirgude, N. T. and Bhagure, G. R., 2015. Heavy Metals and Mineral Elements in Milk of Buffaloes at Boisar-Tarapur Industrial Area, Palghar District, Maharashtra, India. American International Journal of Contemporary Scientific Research. 2(5): 70-77.

Nogueira, T. A. R., Franco, A., He, Z., Braga, V. S., Firme, L. P. and Abreu-Junior, C. H., 2013. Short-term usage of sewage sludge as organic fertilizer to sugarcane in a tropical soil bears little threat of heavy metal contamination. Journal of environmental management. 114: 168-77.

Onat, B., Sahin, U. A. and Akyuz, T., 2013. Elemental characterization of PM2. 5 and PM1 in dense traffic area in Istanbul, Turkey. Atmospheric Pollution Research. 4(1): 101-05.

Pilarczyk, R., Wójcik, J., Czerniak, P., Sablik, P., Pilarczyk, B. and Tomza-Marciniak, A., 2013. Concentrations of toxic heavy metals and trace elements in raw milk of 
Simmental and Holstein-Friesian cows from organic farm. Environmental monitoring and assessment. 185(10): 8383-92.

Raina, A., Raj, J. and Dogra, T. D., 2013, January. Zinc (Zn) Analysis in Milk by Microwave Oven Digestion and Differential Pulse Anodic Stripping Voltametry (DPASV) Technique. In E3S Web of Conferences (Vol. 1). EDP Sciences.

Sahayaraj, P. A. and Ayyadurai, K., 2009. Bioaccumulation of lead in milk of buffaloes from Cooum river belt in Chennai. Journal of Environmental Biology. 30(5): 651-54.

Sansalone, J. J. and Buchberger, S. G., 1997. Partitioning and first flush of metals in urban roadway storm water. Journal of Environmental Engineering. 123(2): 13443.

Shailaja, M., Reddy, Y. S., Kalakumar, B. D. P., Brinda, S. A., Manohar, G. and Kumar, B. D., 2014. Lead and trace element levels in milk and blood of buffaloes (Bubalus bubalis) from Hyderabad, India.Bulletin of environmental contamination and toxicology.92(6): 698-02.

Simsek, O., Gültekin, R., Öksüz, O. and Kurultay, S., 2000. The effect of environmental pollution on the heavy metal content of raw milk. Molecular Nutrition \& Food Research. 44(5): 36063.

Singh, R., Gautam, N., Mishra, A. and Gupta, R., 2011. Heavy metals and living systems: An overview. Indian journal of pharmacology. 43(3): 246.

Swarup, D., Patra, R. C., Naresh, R., Kumar, P. and Shekhar, P., 2005. Blood lead levels in lactating cows reared around polluted localities; transfer of lead into milk. Science of the Total Environment. 347(1-3): 106-10.

Tekaya, N., Saiapina, O., Ouada, H. B., Lagarde, F., Ouada, H. B. and JaffrezicRenault, N., 2013. Ultra-sensitive conductometric detection of heavy metals based on inhibition of alkaline phosphatase activity from Arthrospira platensis. Bioelectrochemistry. 90: 24-29.

Tripathi, R.M., Raghunath, R., Sastry, V.N. and Krishnamoorthy, T.M., $1999 . \quad$ Daily intake of heavy metals by infants through milk and milk products. Science of the total environment. 227(2-3): 229-35.

Valko, M. M. H. C. M., Morris, H. and Cronin, M. T. D., 2005. Metals, toxicity and oxidative stress. Current medicinal chemistry. 12(10): 1161-208.

Zain, S. M., Behkami, S., Bakirdere, S. and Koki, I. B., 2016. Milk authentication and discrimination via metal content clustering- A case of comparing milk from Malaysia and selected countries of the world. Food Control. 66: 306-14.

Zodape, G. V., Dhawan, V. L. and Wagh, R. R., 2012. Determination of metals in cow milk collected from Mumbai city, India. Srilanka: Eco Revolution Colombo. 270-74.

\section{How to cite this article:}

Choodamani Chandrakar, Sudhir Kumar Jaiswal, A.K. Chaturvedani, Sambhuti Shankar Sahu, Monika and Upendra Wasist. 2018. A Review on Heavy Metal Residues in Indian Milk and their Impact on Human Health. Int.J.Curr.Microbiol.App.Sci. 7(05): 1260-1268. doi: https://doi.org/10.20546/ijcmas.2018.705.152 